\title{
Les élites religieuses dans l'arène du développement
}

Sten Hagberg

\section{OpenEdition}

1 Journals

Édition électronique

URL : http://journals.openedition.org/apad/4071

DOI : 10.4000/apad.4071

ISSN : 1950-6929

Éditeur

LIT Verlag

Édition imprimée

Date de publication : 1 août 2011

\section{Référence électronique}

Sten Hagberg, "Les élites religieuses dans l'arène du développement », Bulletin de I'APAD [En ligne], 33 | 2011, mis en ligne le 19 mars 2012, consulté le 23 septembre 2020. URL : http:// journals.openedition.org/apad/4071 ; DOI : https://doi.org/10.4000/apad.4071

Ce document a été généré automatiquement le 23 septembre 2020.

Bulletin de l'APAD 


\section{Les élites religieuses dans l'arène du développement}

\section{Sten Hagberg}

1 Le présent numéro du Bulletin de l'APAD traîte de la relation ambigue entre religion et développement, particulièrement des organisations chrétiennes et musulmanes impliquées dans le développement dans différents pays ouest-africains. Ces organisations basées sur la foi défient les idées reçues et les différentes contributions à ce numéro soulignent la nouvelle visibilité de la religion dans l'arène du développement.

2 Ce numéro du Bulletin de l'APAD est le premier à être produit au département d'anthropologie culturelle et d'ethnologie, Université d'Uppsala. Les propositions que nous sollicitons pour notre revue sont aussi bien des numéros thématiques que des contributions individuelles. Le présent numéro marque aussi la dimension bilingue de l'APAD : deux contributions en anglais et deux contributions en français avec des versions complètes de l'introduction dans les deux langues! 